\title{
PERANCANGAN TRANSFORMASI INSTITUSI PENYELENGGARA DAN PENGELOLA SERTIFIKASI HALAL DI INDONESIA DENGAN PENDEKATAN SOFT SYSTEM METHODOLOGY: STUDI KASUS DI LPPOM MUI
}

\author{
DESIGN OF MANAGING AND ADMINISTERING INSTITUTION TRANFORMATION OF HALAL \\ CERTIFICATION IN INDONESIA WITH SOFT SYSTEM METHODOLOGY APPROACH
}

\author{
Sumunar Jati*), Musa Hubeis ${ }^{* *}$, dan Gendut Suprayitno ${ }^{* * *}$ \\ *) Magister Pengembangan Industri Kecil Menengah, Sekolah Pascasarjana IPB University \\ Jl. Andi Hakim Nasution, Kampus IPB Baranangsiang, Bogor 16144, Indonesia \\ ${ }^{* *}$ Departemen Manajemen, Fakultas Ekonomi dan Manajemen, IPB University \\ Jl. Kamper, Kampus IPB Darmaga, Bogor 16680, Indonesia \\ ***) Program Magister Teknik Industri, Institut Sains dan Teknologi Nasional \\ Jl.Moh Kahfi II Srengseng Sawah Jagakarsa Jakarta Selatan 12640, Indonesia
}

\begin{abstract}
Recently, halal industries have shown impressive growth in global and national market levels. The purpose of this research is designing the managing and administering institution of halal certification (LPPOM MUI) in order to maintain its functions and roles in the new era of regulations (UUJPH) and the growing of halal ecosystem in industrial digital era 4.0. Soft System Methodology (SSM) is used as the methodology. SSM is an organization process modeling that can be used to solve unstructure general problem and management changing. Rich Picture, Root Definition, and Conceptual Model are presented in this paper. Data was collected by using Focus Group Discussions, involved in the process and in-depth interviews with the Government, MUI, LPPOM MUI, business player, and the public community of halal. The focus of this research is getting knowledge of people, their behaviours, their relationships and their influence to LPPOM MUI transformation and the development of corporate and operational strategies. Based on the analysis, there are eight main results as a key strategy of institution transformation, as follows:(i)identification of people, (ii) institution form, (iii) vision, mission, culture, and values evaluation, (iv) operational evaluation based on resource-based view, (v) legal entity transformation, (vi) managerial improvement, (vii) measurement of marketing and financial performance, and (viii) risk mitigation.
\end{abstract}

Keywords: business strategy, halal regulation, soft system methodology, transformation

\begin{abstract}
Abstrak: Industri halal menunjukkan pertumbuhan pasar yang mengesankan dalam beberapa tahun terakhir di tingkat global dan nasional. Tujuan penelitian ini adalah untuk merancang transformasi institusi penyelenggara dan pengelola sertifikasi halal, yaitu LPPOM MUI agar fungsi dan perannya tetap berkelanjutan di era regulasi baru (UUJPH) dan tumbuhnya ekosistem halal di era digital industri 4.0. Metodologi yang digunakan adalah Soft System Methodology (SSM). SSM adalah metode pemodelan proses organisasi yang dapat digunakan untuk penyelesaian masalah umum yang tidak terstruktur. Data diambil dengan menggunakan Focus Grup Discussion, terlibat dalam proses dan wawancara mendalam dengan Pemerintah, MUI, LPPOM MUI, pelaku usaha dan masyarakat peduli halal. Fokus penelitian ini adalah untuk mendapatkan pengetahuan tentang para aktor, perilakunya, hubungan dan pengaruhnya terhadap proses transformasi LPPOM dan pengembangan strategi corporate dan operasional. Dari analisis tersebut, diperoleh delapan hasil utama sebagai strategi kunci dalam transformasi institusi, yaitu (i) identifikasi aktor pelaku, (ii) bentuk kelembagaan, (iii) evaluasi visi, misi, culture dan value, (iv) evaluasi operasional berbasis resource-based view, (v) transformasi legalitas institusi, (vi) perbaikan manajerial, (vii) pengukuran kinerja pemasaran dan finansial, dan (viii) rencana mitigasi resiko.
\end{abstract}

Kata kunci: regulasi halal, strategi bisnis, soft system methodology, transformasi

\footnotetext{
${ }^{1}$ Corresponding author:

Email:sjati69@gmail.com
} 


\section{PENDAHULUAN}

Industri halal dalam beberapa tahun terakhir menunjukkan pertumbuhan pasar yang mengesankan. Menurut laporan Global Islamic Economy Report (GIEI, 2018/19), pasar halal dunia diluar sektor finansial adalah sebesar US\$ 2,2 trilyun dengan pertumbuhan 5,2\% per tahun untuk 6 sektor industri halal yaitu pangan, obat, kosmetika, wisata, media dan rekreasi,serta modest fashion. Indonesia tercatat sebagai negara dengan tingkat impor makanan halal tertinggi yaitu USD 169,7 milyar. Sebagai negara dengan jumlah penduduk muslim tertinggi di dunia, yaitu 267 juta $(87,2 \%$ penduduk Indonesia atau $13 \%$ populasi muslim dunia) (CIA, 2020), Indonesia menjadi pasar besar bagi produk halal. Peringkat Indonesia untuk ekonomi syariah global meningkat dari ke-10 di tahun 2018 menjadi peringkat ke-5 ditahun 2019. Hal ini didorong terutama oleh peningkatan pada peringkat makanan halal dan wisata halal (Bappenas, 2018). Industri halal saat ini telah menjadi isu global dalam perdagangan internasional.

Menurut Azam dan Abdullah (2020), pertumbuhan pasar produk halal akan terus meningkat seiring (i) pertumbuhan penduduk muslim dunia sebesar 1,8 persen per tahun, yaitu dari jumlah 1,6 milyar di tahun 2010 menjadi 2,2 milyar di tahun 2030 (Nurrachmi, 2017), (ii) peningkatan pertumbuhan ekonomi dan daya beli antar negara muslim (OIC countries) serta (iii) tumbuhnya potensi market di negaranegara non-muslim dan pemain industri halal global. Keberterimaan produk halal bagi non-muslim karena konsep halal memberikan landasan yang baik untuk pola makan dan gaya hidup sehat serta mengedepankan unsur keamanan, kebersihan, dan kualitas produk dan layanan (Golnaz et al. 2010).

Besarnya jumlah penduduk Muslim dengan nilai konsumsimakanan halal terbesar di duniaternyatabelum menjadi pendorong bagi Indonesia untuk meningkatkan produksi makanan halal yang tersertifikasi. Kondisi industri syariah di Indonesia saat ini menunjukkan bahwa sebagian besar konsumsi produk yang sesuai syariah atau halal di Indonesia masih dipasok dari produk-produk impor. Pasokan produk halal yang diimpor untuk memenuhi kebutuhan permintaan dalam negeri juga secara tidak langsung mempengaruhi neraca perdagangan Indonesia yang saat ini terus mengalami peningkatan defisit (Bappenas, 2018).
Indonesia saat ini telah memiliki regulasi terkait jaminan produk halal, salah satunya adalah Undangundang Jaminan Produk Halal (UUJPH) Nomor 33 tahun 2014 tentang Jaminan Produk Halal. Undangundang tersebut berisikan kewajiban semua produk yang beredar di kawasan Republik Indonesia harus memiliki sertifikat halal, kecuali yang ada keterangan tidak halal di kemasannya. Peratuan ini berlaku mulai 17 Oktober 2019. Adanya penerapan jaminan produk halal diharapkan menjadi modal pembentukan pertumbuhan ekonomi umat berbasis syariah di semua lini pertumbuhan. Menurut Bappenas (2018), Indonesia menuju target PDB sebesar Rp24.000 trilyun dengan pendapatan per kapita US\$5.930 pada tahun 2024.

UUJPH mengamanatkan pembentukan Badan Penyelenggara Jaminan Produk Halal (BPJPH). Wewenangnya merumuskan dan menetapkan kebijakan jaminan produk halal, norma, standar, prosedur, dan kriteria jaminan produk halal. Kewenangan lainnya adalah menerbitkan dan mencabut sertifikat halal, label halal pada produk, mendaftarkan sertifikat halal pada produk luar negeri, mengakreditasi Lembaga Pemeriksa Halal (LPH), mendaftarkan auditor halal, melakukan pengawasan terhadap jaminan produk halal, membina auditor halal, dan bekerja sama dengan lembaga dalam dan luar negeri di bidang penyelenggaraan jaminan produk halal.

Adanya perubahan regulasi tersebut membuat LPPOM MUI terdampak pada terpotongnya kewenangan yang ada selama ini. UUJPH membuka kesempatan bagi masyarakat dan pemerintah untuk mendirikan LPHLPH baru. Disisi lain dengan terbukanya perdagangan bebas antar negara serta pertumbuhan e-commerce di Indonesia sebesar 78 persen (Zuraya, 2019) di era revolusi industri 4.0 dan society 5.0 mengharuskan setiap entitas dalam rantai pasok produk industri halal termasuk Lembaga Sertifikasi Halal konvergen dengan budaya kerja yang cepat, transparan serta comply dengan teknologi informasi dan komunikasi (Kemenperin, 2018) serta standar Internasional, agar keberterimaan produk atau jasa halal nasional menjadi lebih luas. Kondisi kelembagaan LPPOM MUI saat ini yang masih didominasi sifat lembaga induknya yaitu perkumpulan sosial keagamaan, memerlukan strategi transformasi yang tepat agar LPPOM MUI mampu menjadi LPH yang memiliki keunggulan bersaing dalam mewujudkan keberlanjutan peran dan fungsinya. 
Penelitian ini berfokus kepada strategi transformasi kelembagaan. Penelitian di bidang transformasi kelembagaan telah banyak dilakukan, termasuk penelitian di bidang sosial keagamaan. Penelitian transformasi kelembagaan di ranah sosial keagamaan sebagian besar dilakukan pada lembaga pendidikan seperti penelitian Hasyim (2015) yang meneliti transformasi lembaga pendidikan pesantren. Untuk lembaga yang bersifat non profit, sosial keagamaan dan non-pendidikan belum banyak diteliti. Pada umumnya penelitian transformasi lembaga banyak diarahkan ke lembaga profit (perusahaan dan koperasi) atau lembaga pengembangan masyarakat semi profit (lembaga wakaf, kelompoktani,lembagadesa, danlain-lainnya). Beberapa penelitian kelembagaan di antaranya, Zulfiandri et al. (2017) meneliti transformasi kelembagaan petani secara vertikal dengan memperhatikan biaya-biaya transaksi dan kelayakan antar level transformasi dan penelitian yang dilakukan Praseningtyas et al. (2019) tentang kelembagaan petani organik di Jawa Barat. Novani et al. (2014) menggunakan pendekatan sistem lunak (soft system) untuk mengkaji pengembangan klaster batik di Solo dengan pendekatan kerjasama antar stake holder. Penelitian yang menggunakan pendekatan Soft System dalam merancang model transformasi kelembagaan telah banyak dilakukan, namun lembaga non-profit, sosial keagamaan dan halal belum pernah dilakukan. Penelitian ini mengambil posisi tersebut.

Berdasarkan rumusan masalah, maka penelitian ini bertujuan untuk menghasilkan rancangan transformasi LPPOM MUI sebagai Institusi Penyelenggara dan Pengelola Sertifikasi Halal yang telah berlangsung 30 tahun di Indonesia dengan memanfaatkan kerangka kerja Soft System Methodology (SSM). SSM belum digunakan dalam kegiatan sertifikasi halal di Indonesia, oleh karena itu, penelitian ini merupakan action research.

\section{METODE PENELITIAN}

Penelitian ini menggunakan analisis deskriptif kualitatif yaitu riset tindakan berbasis Metode Serba Sistem Lunak atau Soft Systems Methodology atau lebih dikenal dengan SSM-based action research yang menggunakan tujuh langkah dari teori Checkland serta checklist dari enam elemen dasar pada langkah ketiga SSM yaitu CATWOE (Clients, Actors, Transformation, Weltanschaung, Owner, Environment).
Penelitian ini dilaksanakan di Jakarta dan Bogor dari September 2019 sampai dengan Mei 2020. Perancangan transformasi LPPOM MUI dilakukan sesuai tahapan metodologi Soft System Methodology (Checklend, 2010). Sumber utama dalam pengambilan data diperoleh secara langsung dari narasumber baik melalui wawancara dan diskusi FGD, yaitu MUI, LPPOM Pusat, LPPOM Provinsi seluruh Indonesia, Pemerintah (BPJPH, KNEKS), Perwakilan Pelaku Usaha, Komunitas Masyarakat Peduli Halal.

Proses pengambilan data dilakukan dengan cara berbeda pada setiap langkah soft system methodology (SSMS). Proses wawancara semi terstruktur dilakukan pada tahap awal dalam rangka pendefinisian masalah dan gambaran situasi masalah yang komplek. Proses wawancara dilakukan kepada stakeholder pemerintah (BPJH dan KNEKS), MUI, LPPOM, Pelaku Usaha dan Komunitas Masyarakat Peduli Halal. Proses FGD dilakukan pada tahap akhir, saat membandingkan model konseptual dengan situasi dunia nyata. Peserta FGD terdiri dari perwakilan MUI, LPPOM Pusat, Perwakilan LPPOM Provinsi, Perwakilan Pelaku Usaha dan Komunitas Masyarakat peduli Halal. Pengumpulan data sekunder dilaksanakan dengan metode studi pustaka.

Menurut Checkland (1990), "SSM is not a tool or technique to be used occasionally but a way to think and act every day". Checkland, P. dan Jim. S. (1999) mengembangkan Soft System Methodology (SSM) yang merupakan metodologi action research yang ditujukan untuk mengeksplorasi, menanyakan dan belajar mengenai situasi permasalahan yang tidak terstruktur (soft system) agar dapat memperbaikinya. Ide dasar dari pemikiran soft system ialah konsep sistem digunakan sebagai cara untuk menyelidiki ke dalam dunia yang dipersepsikan. Ide-ide sistem berdasarkan konsep 'a whole' dimana suatu organisasi dapat dilihat sebagai suatu keseluruhan yang utuh dimana keseluruhan (the whole) lebih berarti daripada jumlah bagian-bagiannya.

Checkland (1999) dan Wilson (2001) mengembangkan set alat untuk membantu pengguna melakukan langkahlangkah seperti: Rich picture, Model konseptual, CATWOEdanFormalSystemsModel.SSMmemandang bahwa dunia nyata apa pun ditandai dengan sudut pandang dari setiap orang yang berada di dalam entitas dunia nyata tersebut, dan bahkan berbagai sudut pandang itu acapkali saling bertentangan satu dengan yang 
lainnya. Dunia nyata bersifat kompleks, problematis, misterius, dan ditandai dengan pertentangan antarsudut pandang (worldviews) (Hardjosoekarto, 2012). Menurut Checkland dan Poulter (2006), dunia nyata secara terus-menerus dikreasi dan direkreasi kembali oleh pikiran, perbincangan dan tindakan manusia.

Menurut Hardjosoekarto (2012), SSM merupakan alat intelektual guna memahami situasi dunia nyata yang dianggap problematis. Analisisnya bersifat insider, dengan sepenuhnya mengolah sudut pandang manusia, dan hanya berurusan dengan satu-satunya tipologi serba sistem, yaitu serba sistem aktivitas manusia. Ciri-ciri utama SSM menurut Hardjosoekarto (2012) adalah pemahaman dan analisis situasi masalah, analisis relasi dan peran para pihak terkait dan analisis relasi dan peran politik serta sistem para pihak terkait. Hardjosoekarto menambahkan bahwa dalam SSM, yang menjadi perhatian adalah situasi dunia nyata yang dianggap problematis. SSM lebih menitikberatkan pada perceived real-world problematical situations, bukan problems of the real world.
Tujuh penahapan SSM menurut Checkland dan Scholes (1990): Problem situation considered problematic (Menentukan dan memahami situasi masalah), Problem situation expressed (Menyatakan situasi masalah), Root definition of relevant of purposeful activity systems (Memilih sudut pandang untuk melihat situasi dan menghasilkan definisi akar masalah), Conceptual models of the systems named in the root definitions (Memilih sudut pandang untuk melihat situasi dan menghasilkan definisi akar masalah), Comparison of models and real (Membandingkan model dengan dunia nyata), Changes systematically desirable, culturally feasible (Menyatakan perubahan yang diharapkan dan mungkin dilakukan), Action to improve the situation (Melakukan tindakan untuk meningkatkan situasi dunia nyata). Pada penelitian ini proses tahap proses pernyataan situasi masalah menggunakan pendekatan PESTEL. Ho (2014) menyatakan bahwa PESTLE analisis sesuai untuk proses system thinking. Checkland mendefinisikan 7 tahap dalam SSM yang dikenal juga dengan nama Checkland protocol seperti yang tergambar dalam Gambar 1.

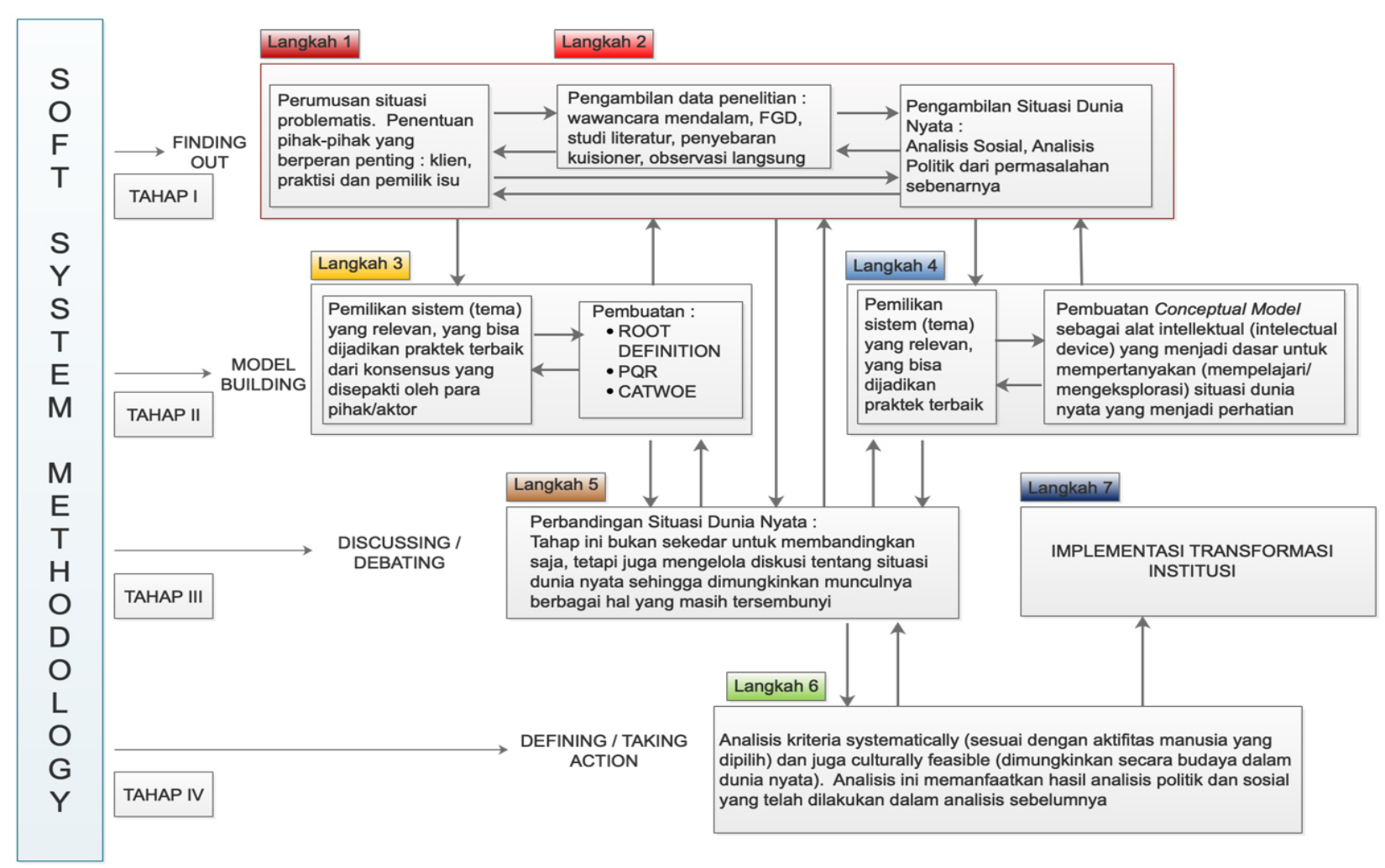

Gambar 1. Tahapan Penelitian menggunakan SSM 


\section{HASIL}

\section{Pemaparan Permasalahan}

Berdasarkan tahapan SSM, pengungkapan dan penggambaran masalah merupakan tahap kesatu dan tahap kedua. Tahap kesatu dan kedua ini merupakan gambaran dari dunia nyata (real world). Pada proses SSM, hal ini berupa pengungkapan situasi permasalahan (problem situation expressed). Pada tahap satu dan dua disajikan dua bagian yaitupengungkapan situasimasalah dan gambaran situasi masalah (rich picture). Seluruh tahapan ini dilaksanakan dengan cara menghimpun pendapat para praktisi dan para pakar, praktisi dan pemerintah di bidang halal serta praktisi kelembagaan melalui pendekatan formal dan informal dalam berbagai pertemuan, diskusi, telaah dokumen, hingga diskusi kelompok (FGD). Tahapan pengungkapan situasi masalah didapat dengan menggunakan telaah dokumen, FGD dan wawancara mendalam, sedangkan tahapan gambaran situasi masalah diperoleh dengan cara pendekataan diskusi dan pertemuan informal dengan pakar dalam rangka memperoleh umpan balik dari rich picture yang dibuat. Bentuk interaksi penggalian pendapat dan persepsi juga dilakukan pada saat proses konfirmasi hasil root definition, purposive activity model, dan pembandingannya dengan dunia nyata (real world).

Wawancara merupakan alat bagi pembuktian dan konfirmasi ulang (rechecking) terhadap informasi yang telah diperoleh sebelumnya. Teknik wawancara yang digunakan dalam penelitian ini adalah wawancara mendalam (in-depth interview). Sebelum melakukan wawancara terlebih dahulu dilakukan persiapan bahan diskusi dan diakhiri dengan merangkum seluruh hasil diskusi dan kajian tersebut.

Pada tahapan pengungkapan situasi masalah Checkland dan Poulter (2010) menyarankan menggunakan analisis intervensi (analysis one), analisis sosial (analysis two),dan analisis politik (analysis three). Pada tahapan ini peneliti juga menggunakan analisis PESTEL (Johnson et al. 2008). Berdasarkan hasil wawancara dan pengamatan di lapangan bahwa stakeholder yang berperan penting dalam proses transformasi yakni, pemerintah, MUI, LPPOM MUI, Pelaku Industri, dan Masyarakat. Berikut ini adalah tahapan pengungkapan permasalahan kelembagaan di LPPOM MUI.

\section{Analisis Intervensi}

Analisis intervensi difokuskan kepada penetapan lima pihak yang berperan sangat penting dalam kaitannya dengan situasi permasalahan transformasi LPPOM MUI.

Klien (Client) - C : : Peneliti

Praktisi (Practitioner)-P : Peneliti

Pemilik isu (Problem Owner) - $\mathrm{O}$ :

(1) Pemerintah (kementrian agama dan LPNK)

(2) MUI Pusat dan MUI Provinsi

(3) LPPOM MUI

(4) Pelaku Industri

(5) Masyarakat

Hasil analisis intervensi ini merupakan identifikasi dari gambaran situasi permasalahan yang ada pada model setiap pemangku kepentingan. Bromley (1989) menyatakan terdapat perbedaan konten dan konteks dalam formulasi kebijakan pada setiap level organisasi. Peran masing-masing pihak dalam JPH sebagai pemangku kepentingan berbeda. Pemerintah berperan sebagai regulator dan penyelenggara JPH, MUI sebagai lembaga otoritas "pengesah" kehalalan, LPPOM MUI sebagai lembaga pemeriksa kehalalan, dan industri serta masyarakat sebagai pihak yang memerlukan JPH. Semua pihak yang berkepentingan ini diatur dalam aspek legal (UU JPH, 2014) dan mengikuti norma yang disepakati bersama.

\section{Norma}

Menurut Checkland dan Poulter (2010) norma adalah perilaku yang diharapkan yang terkait dengan peran. Norma yang ada dalam Jaminan Produk Halal (JPH) dengan peran yang dilakukan oleh setiap pemangku kepentingan. Norma yang berlaku di masing-masing pemangku kepentingan yaitu:

1. Pemerintah pusat provinsi dan kabupaten tunduk pada kode etik dalam menjalankan kegiatannya. Kode etik yang berlaku pada pemerintah adalah undang-undang peraturan-peraturan baik pusat maupun daerah yang mengatur mekasnisme kerja pemerintah.

2. MUI baik Pusat maupun Provinsi berpegang kepada Anggaran Dasar/Anggaran Rumah Tangga dan kode etik organisasi yang telah disepakati bersama oleh seluruh anggota organisasi dan kesepakatan formal dan. 
3. LPPOM MUI berpegang pada kesepakatan formal dengan pelaku industri yang telah disepakati bersama. Kesepakatan ini saling mendukung dan memfasilitasi pemberian sah.

Nilai

Nilai adalah standar atau kriteria perilaku mana yang sesuai dengan peran (Checkland dan Poulter, 2010). Pada tataran pemerintah, MUI dan LPPOM MUI dimiliki masing-masing adalah sebagai berikut :

1. Pemerintah menyusun kebijakan sesuai pilar RPJMN IV (2020-2024), yaitu kesejahteraan masyarakat yang terus meningkat dan struktur ekonomi yang maju dan kokoh.

2. MUI memberikan nasihat dan fatwa mengenai masalah keagamaan dan kemasyarakatan kepada Pemerintah dan masyarakat (MUI, 2020)

3. LPPOM MUI menganut nilai-nilai integritas, profesional, inovasi, service excellence, dan sinergi (LPPOM MUI, 2020)

\section{Gambaran Situasi Problematik}

Untuk mengidentifikasi situasi problematik dalam JPH maka dilakukan wawancara atau diskusi mendalam yang dilakukan dengan beberapa pemilik isu (issue owner) dari pemangku kepentingan (stakeholder). Selain mengidentikasi situasi problematik diskusi mendalam juga dilakukan untuk mengetahui situasi problematik dari strategi kebijakan pengembangan JPH. Berikut ini digambarkan pendapat, pandangan, dan pernyataan dari narasumber tentang masalah yang dirasakan oleh pemerintah, MUI dan LPPOM dalam pengembangan JPH. Pendapat pakar ini didapatkan dari hasil wawancara langsung maupun pendapat saat acara Focus Group Discussion (FGD). Hasil wawancara dan pendapat dalam FGD dijabarkan berupa resume sebagai berikut (Tabel 1).

Tabel 1. Hasil pendapat dan pikiran pemangku kepentingan tentang situasi problematis tantangan kelembagaan organisasi LPPOM MUI ke depan

\begin{tabular}{ll}
\hline Pemangku Kepentingan & Pendapat dan Pikiran Pemangku Kepentingan \\
\hline Birokrat/Pemerintah & LPPOM MUI tetap dapat berperan sebagai Lembaga Pemeriksa Halal (LPH) \\
& $\begin{array}{l}\text { LPPOM MUI dapat berperan banyak dalam penetapan standar halal nasional berdasarkan } \\
\text { pengalaman sertifikasi halal selama ini. LPPOM MUI telah meletakkan dasar-dasar sertifikasi } \\
\text { halal dan kriteria halal di buku HAS23000 }\end{array}$
\end{tabular}

LPPOM MUI/MUI dapat berperan dalam penilaian kriteria pemenuhan sebuah Kawasan industri halal.

LPPOM MUI menjadi Lembaga Sertifikasi Halal (LSH) yang diakreditasi pada skema KAN yaitu ISO17065 dan DPLS21, serta skema akreditasi negara UEA.S 2055-2, sehingga LPPOM MUI tetap dapat terlisted di negara UEA sebagai LSH yang diakui negara tersebut. Hal ini dapat membantu kepentingan perdagangan produk halal nasional untuk masuk Kawasan negara teluk dan OKI.

Data produk dan produsen halal dari LPPOM MUI dapat menjadi datawarehouse dalam membangun ekosistem halal di Indonesia.

LPPOM MUI dapat terlibat dalam penetapan produk halal sebagai bagian pengembangan ekonomi Syariah sebagai pilar ekonomi Syariah.

LPPOM MUI berpotensi menjadi LPH nasional untuk mendukung pasar ekspor industri halal.

Majelis Ulama Indonesia (MUI)

\section{LPPOM MUI harus:}

Meningkatkan transparansi kinerja manajemen

Antisipasi risiko terhadap reputasi karena membawa nama MUI

Harus mencari kepercayaan (trust) dari pelanggan dengan menjadi yang paling prima

LPPOM MUI seluruh Indonesia adalah satu entitas antara pusat dan daerah

LSP yang dibentuk oleh LPPOM MUI dinaikkan statusnya menjadi LSP MUI sesuai amanat UUJPH

MUI akan membentuk Dewan Halal Nasional (DHN) untuk menjalankan fungsi UUJPH yang tidak dapat dikerjakan oleh LPPOM MUI sebagai LPH, yaitu (akreditasi LPH, penetapan standar halal MUI, edukasi dan sosialisasi halal) 
Tabel 1. Hasil pendapat dan pikiran pemangku kepentingan tentang situasi problematis tantangan kelembagaan organisasi LPPOM MUI ke depan (lanjutan)

\begin{tabular}{|c|c|}
\hline Pemangku Kepentingan & Pendapat dan Pikiran Pemangku Kepentingan \\
\hline \multirow[t]{8}{*}{ Pelaku Industri Halal } & $\begin{array}{l}\text { Agar LPPOM dapat membuat skema sertifikasi halal yang dapat mempercepat proses sertifikasi } \\
\text { halal }\end{array}$ \\
\hline & Agar auditor halal memiliki standar kompetensi yang sama \\
\hline & $\begin{array}{l}\text { Agar produk yang sudah disertifikasi oleh LSH LN ketika diproses oleh LPPOM tidak terlalu } \\
\text { lama (perlu harmonisasi standar dengan LSH LN) }\end{array}$ \\
\hline & Agar system IT tidak sering down (perlu antisipasi pelayanan IT yang lebih baik) \\
\hline & Perlunya jaminan kepastian waktu sertifikasi selesai (terkait jadwal launching produk) \\
\hline & $\begin{array}{l}\text { Terkait perkembangan UUJPH agar dapat memberikan informasi yang lebih lengkap dan } \\
\text { update }\end{array}$ \\
\hline & Agar ada transparansi biaya sertifikasi halal yang mudah diakses perusahaan \\
\hline & $\begin{array}{l}\text { LPPOM MUI pusat dan daerah menjadi satu entitas untuk memudahkan proses sertifikasi } \\
\text { secara nasional }\end{array}$ \\
\hline \multirow[t]{9}{*}{ LPPOM MUI } & Penguatan posisi LPPOM MUI dalam masa persaingan \\
\hline & Perlu revitalisasi visi, misi, values, culture dan strategi LPPOM MUI di era persaingan \\
\hline & Modernisasi sistem kantor dengan menerapkan ERP \\
\hline & Perubahan pilihan bentuk dan sifat organisasi \\
\hline & Kejelasan dalam system grading jabatan \\
\hline & Comply terhadap semua regulasi terkait HR \\
\hline & Perlu adanya system penilaian kinerja (KPI) \\
\hline & Kejelasan pembagian antar unit kerja tanpa ada irisan yang sejenis \\
\hline & Perlunya sistem penjadwalan yang lebih baik berbasis PPIC \\
\hline \multirow{2}{*}{$\begin{array}{l}\text { Halal Community Care } \\
\text { (Masyarakat Peduli } \\
\text { Halal) }\end{array}$} & $\begin{array}{l}\text { Agar LPPOM dapat bekerjasama sama dengan halal community care dengan lebih intensif } \\
\text { untuk awareness halal pada pelaku industri khususnya IKM. }\end{array}$ \\
\hline & Terintegrasi LPPOM pusat dan daerah \\
\hline
\end{tabular}

\section{Rangkuman Situasi Problematis}

Analisis situasi problematis merupakan tahapan pertama dari SSM. Hasil dari analisis situasi ini akan dipecahkan melalui tahapan SSM berikutnya sehingga diketahui aksi apa saja yang perlu diambil. Situasi problematis yang dihadapi dalam JPH dapat dirangkum berdasarkan pendapat para pemangku kepentingan di atas. Secara lengkap disampaikan pada Tabel 1.

\section{Rich Picture}

Rich Picture dalam SSM digunakan sebagai cara untuk pengungkapan (expressed) situasi dunia nyata yang dianggap problematis (Hardjosoekerto 2012). Penyajian rich picture adalah bentuk gambaran informasi tentang masalah yang terjadi didunia nyata dalam proses transformasi LPPOM MUI dan menunjukkan semua pemangku kepentingan (stakeholders) untuk ikut berperan dan menjadi perhatian pokok mereka. Checkland dan Poulter (2010) menyatakan bahwa peneliti dapat menyampaikan situasi problematis secara leluasa dengan gambar, garis, tanda atau ikon khusus. Rich picture situasi problematik tersebut dapat dilihat pada Gambar 2.

Root definition dan Model Konseptual Proses Transformasi LPPOM

Pada bagian ini dilakukan dua tahapan yaitu, tahap ketiga merupakan root definition, dan tahap keempat menyusun model konseptual. Tahap ketiga ini merupakan tahap pra pemodelan, dimana dipaparkan dalam formulasi kalimat PQR. Sedangkan tahapan keempat merupakan inti dari kegiatan penyusunan model konseptual. 

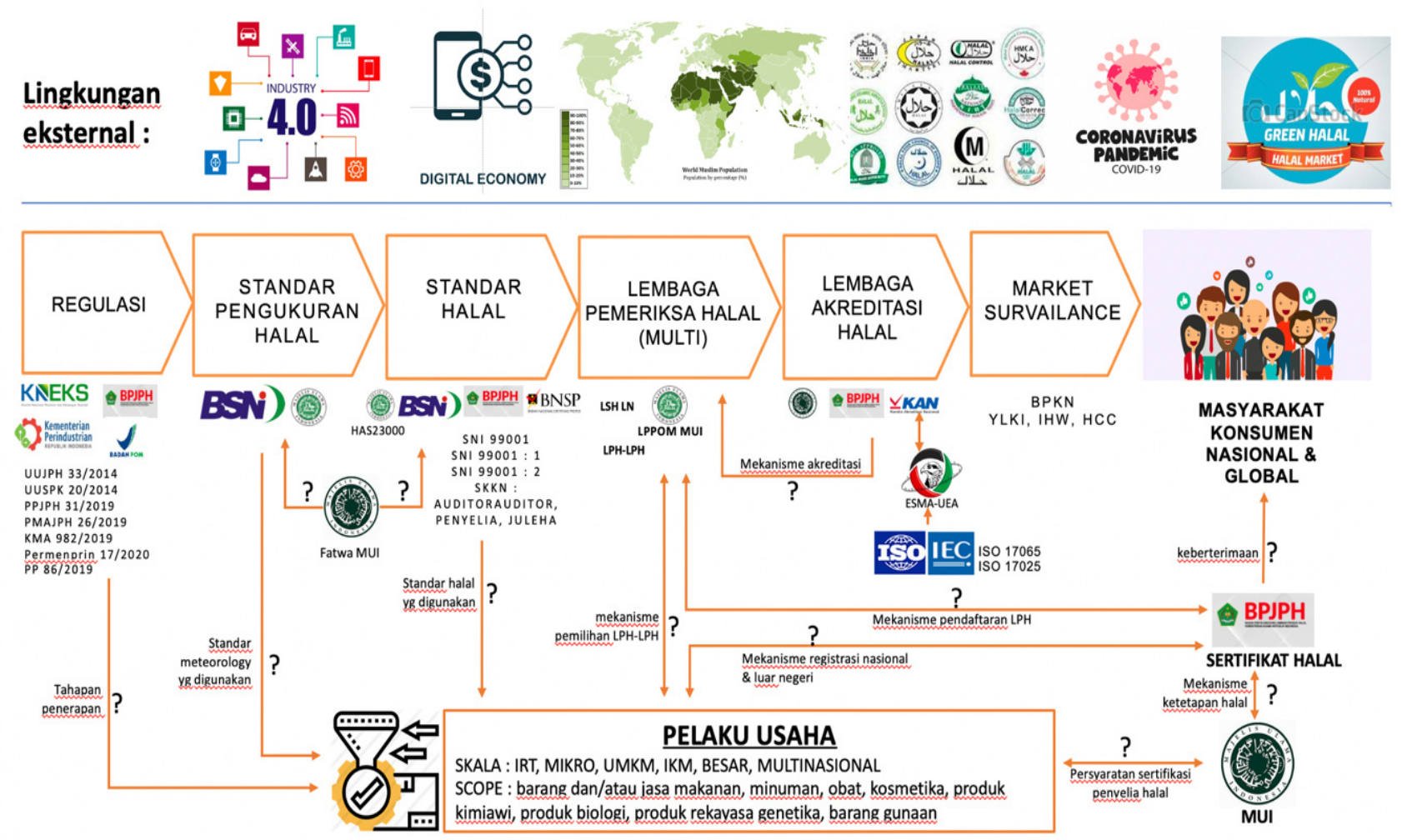

Gambar 2. Rich Picture Situasi Problematis JPH di Indonesia

\section{Root definition}

Root definition merupakan cara untuk menggambarkan sistem untuk proses pemodelan sistem. Checkland dan Poulter (2009) pada tahapan ini menggunakan rumus umum $\mathrm{PQR}$ dalam menyusun root definiton (RD). Formula PQR: do P, by Q, in order to help R. Pada formula ini akan menjawab apa, bagaimana dan mengapa dalam penelitian. Supaya RD yang disusun benar-benar dapat digunakan sebagai model konseptual, maka RD tersebut perlu diuji disempurnakan dengan alat bantu analisis CATWOE (Costummers, Actors, Transformasi, Worldview, Owner, Environment) dalam menganalisis proses transformasi (Hardjosoekarto, 2012). RD dan CATWOE merupakan sumber dari pembuatan aktivitas-aktivitas pada purposeful activity model yang digunakan merujuk pada proses perubahan lembaga LPPOM MUI.

Pada tahap ketiga dan keempat ini telah diidentifikasi bagian yang merupakan sistem aktivitas Lembaga LPPOM MUI yang mempunyai peran relevan dengan situasi problematis dalam proses transformasi LPPOM MUI, yaitu "Sistem transformasi institusi penyelenggara dan pengelola sertifikasi halal yaitu LPPOM MUI yang memenuhi harapan MUI, Pemerintah, Pelaku Usaha dan Masyarakat”. Sistem aktivitas manusia yang punya maksud (purposive activity) di atas merupakan bagian dari sistem transformasi kelembagaan LPPOM MUI yang diawali dengan perubahan Lembaga Sertifikasi HalalMUIagar sesuai dengan UU Jaminan Produk Halal. Proses perubahan tersebut merujuk kepada perpindahan (switching) kewenangan sertifikasi halal dari MUI ke pemerintah (BPJPH). Lembaga sertifikasi halal yang eksisting dan memiliki pengaruh kuat sebelumnya adalah LPPOM MUI. Perubahan tata aturan regulasi baru memaksa LPPOM MUI harus menyesuaikan diri agar bisa terus memberikan pelayanan pemeriksaan halal. Selain itu, LPPOM MUI juga harus beradaptasi agar pelayanannya prima dalam konteks industri 4.0 menuju society 5.0. Sistem tersebut di atas dibuatkan root definition $\mathrm{RD}$ dan conceptual model (CM) yang akan menjadi alat intelektual melakukan diskusi dan dialog tentang situasi problematis yang dihadapi dalam rangka perubahan kelembagaan LPPOM MUI. Definisi akar (Root Definition) dari permasalahan di atas adalah sebuah sistem yang dimiliki MUI dan dioperasikan oleh LPPOM MUI dalam rangka bertransformasi menjadi Lembaga Pemeriksa Halal/LPH sesuai amanat UUJPH (P) melalui perubahan bentuk badan hukum dan perancangan transformasi strategi manajerial dan operasional berbasis resource based view (Q), sehingga LPPOM MUI menjadi LPH yang unggul, kompetitif dan berkelanjutan (SCA) (R). 
Berdasarkan hasil root definition CATWOE yang dikumpulkan maka dilakukan penyusunan model transformasi yang mencakup pengumpulan dan penstrukturan aktivitas minimum yang dibutuhkan untuk melakukan proses transformasi dengan menggunakan elemen CATWOE. Model konseptual tersebut terdiri dari aktivitas-aktivitas tujuan yang telah diuji 5E (efficacy, efficiency, effectiveness, elegance, ethicality), yang meliputi :

- Uji efficacy yaitu menguji apakah aktivitas bertujuan tersebut memang menghasilkan keluaran sesuai yang diinginkan.

- Uji efficiency yaitu menguji apakah aktivitas bertujuan tersebut menggunakan sumberdaya minimum.

- Uji effectiveness yaitu menguji apakah aktivitas bertujuan tersebut dapat secara efektif mencapai tujuan jangka panjang yang diinginkan.

- Uji elegance yaitu mengukur apakah proses transformasi yang dilakukan berlangsung elegan; dan

- Uji ethicality yaitu melihat apakah proses transformasi mendapatkan pembenaran secara moral.

Analisis CATWOE Sistem transformasi LPPOM MUI yang memenuhi harapan MUI, Pemerintah, Industri dan Masyarakat: C (Customers): Pemerintah, MUI, Pelaku Usaha bidang sesuai lingkup UUJPH pada skala Besar, IKM, UMKM, dan IRT, serta Masyarakat konsumen; A (Actors): LPPOM MUI; T (Transformation): Transformasi LPPOM MUI dari bentuk badan hukum yang menginduk MUI (perkumpulan) menjadi berbadan hukum usaha dan Transformasi Strategi Manajerial dan Operasional LPPOM MUI berbasis resource based view; W (Worldview): Kolaborasi baik antara LPPOM MUI dan stakeholder MUI serta perbaikan manajerial dan operasional berbasis keunggulan daya saing internal sehingga memberikan manfaat secara finansial dan keberlanjutan perannya; O (Owners): MUI dan LPPOM MUI; E (Enviromental): Pola piker (mindset), Peraturan Organisasi MUI, budaya, birokrasi.

Model konseptual berupa aktivitas kegiatan manusia yang mempunyai maksud (purposeful activity) untuk sistem di atas yang disajikan dalam Gambar 3, adalah LPPOM MUI mempersiapkan lembaga dan personil sebagai persiapan perubahan:

1. Menganalisis aktor dan faktor. Aktor di sini adalah siapa atau lembaga apa saja yang bisa melakukan proses transformasi. Pada konteks makro, lembaga yang mampu membuat keputusan melakukan proses transformasi adalah MUI dan LPPOM MUI. Pada konteks mikro, aktor adalah orang yang mampu dan bisa melakukan proses transformasi beserta faktor-faktor internal dan eksternal yang bisa menggerakkan proses transformasi dan termasuk juga faktor-faktor yang mungkin terjadi di masa depan sehingga antisipasi bisa disiapkan mitigasi risikonya.

2. Mengevaluasi visi, misi dan value institusi LPPOM MUI. Evaluasi dilakukan setelah aktor dan faktor transformasi diketahui sehingga jika diperlukan redefinisi dan kaji-tindak ulang visi, misi dan value LPPOM MUI yang baru.

3. Melakukan evaluasi manajerial dan operasional. Proses evaluasi ini untuk memastikan agar organisasi sesuai dengan visi, misi dan value LPPOM transformasi.

4. Menyusun rancangan transformasi bentuk badan hukum LPPOM MUI. Rancangan organisasi ini menyesuaikan dengan kebutuhan organisasi di saat ini dan di masa depan.

5. Menyusun transformasi strategi manajerial dan operasional. Rancangan strategi transformasi ini diperlukan agar proses perubahan berlangsung dengan soft-landing.

6. Merancang pengukuran keberhasilan transformasi. Ukuran keberhasilan (Key performance indikator) $K P I)$ proses transformasi dirancang agar proses evaluasi dan kontrol mudah dilakukan.

7. Melakukan mitigasi risiko terhadap deviasi yang mungkin terjadi. Proses mitigasi risiko dilakukan mengacu kepada analisis faktor dan dampak transformasi bagi ekologi organisasi.

\section{Kesenjangan Kondisi Ideal Proses Transformasi LPPOM MUI}

Pada tahap ini merupakan tahapan kelima, keenam dan ketujuh dari SSM. Pada tahapan ini peneliti akan membandingkan Model Konseptual yang dihasilkan pada tahapan 3 dan 4 dengan dunia nyata, agar diperoleh paradigma (worldview) yang lebih luas lagi untuk merumuskan saran dan perbaikan. Sistem aktivitas manusia yang memiliki maksud (holon) merupakan alat yang memungkinkan diskusi terkelola untuk bisa menjawab pertanyaan-pertanyaan kritis dengan menggunakan bingkai 5W $1 \mathrm{H}$ (What, When, Where, Who, Why dan How) seperti (i) Apakah model konseptual tersebut terjadi di dunia nyata?, (ii) Kapan aktivitasaktivitas tersebt dapat dilaksanakan?, (iii) Siapa saja 
yang terlibat di dalam aktivitas-aktivitas tersebut?, (iv) Apakah ada kesenjangan model konseptual tersebut dengan dunia nyata? Jika ada, bisakah diperbaiki? (v) Bagaimanakah melakukan perbaikan-perbaikannya?. Pada tahapan ini sangat memungkinkan praktisi SSM mendapatkan kesulitan dalam menjawab pertanyaan yang berkaitan dengan pengukuran kinerja. Kesulitan ini dapat terjadi karena adanya kerumitan dunia nyata (Checkland dan Poulter, 2010). Dengan munculnya beragam sudut pandang ini akan mendorong munculnya keinginan untuk melakukan aktivitas-aktivitas yang mempunyai maksud, yang dapat dijadikan sebagai saran formulasi perubahan, perbaikan atau penyempurnaan atas situasi problematis dunia nyata. Perubahan yang dimaksud harus berasal dari dalam diri organisasi tersebut sendiri. Terdapat hubungan yang signifikan antara keberhasilan organisasi dalam persaingan pada bidangnya dengan kekuatan yang berasal dari internal (Wurjaningrum, 2015). Dalam penelitian ini, strategi transformasi LPPOM diawali dan merupakan hal yang penting dilihat, kekuatan internal yang dimiliki LPPOM. Tabel 2 menampilkan perbandingan antara situasi problematis dunia nyata dengan model konseptual yang telah disusun.

\section{Implikasi Manajerial}

Hasil penelitian menunjukkan bahwa para pemangku kepentingan penyelenggara dan pengelola sertifikasi halal menyepakati bahwa LPPOM MUI harus segera bertransformasi untuk menyesuaikan lembaga dengan regulasi baru dan juga beradaptasi dengan ekosistem era digital industri 4.0. Proses transformasi membutuhkan keputusan manajerial (Direksi) dan pengendali (Pengurus MUI) agar proses transformasi berjalan lancar. Proses transformasi dimulai dari perubahan struktur organisasi di tingkat Pusat yang diikuti di tingkat provinsi. Bentuk organisasi yang disarankan oleh stakeholder adalah lembaga usaha, agar bisa bersaing dengan pelaku LPH lainnya.

Proses transformasi ini membutuhkan strategi induk (grand strategy), dalam implementasi detilnya. Strategi induk ini berbasiskan kompetensis internal LPPOM. Strategi ini perlu dipersiapkan dengan matang dan dibuat dengan memperhatikan masukan stakeholder pada transformasi bentuk kelembagaan dan posisi status legal.

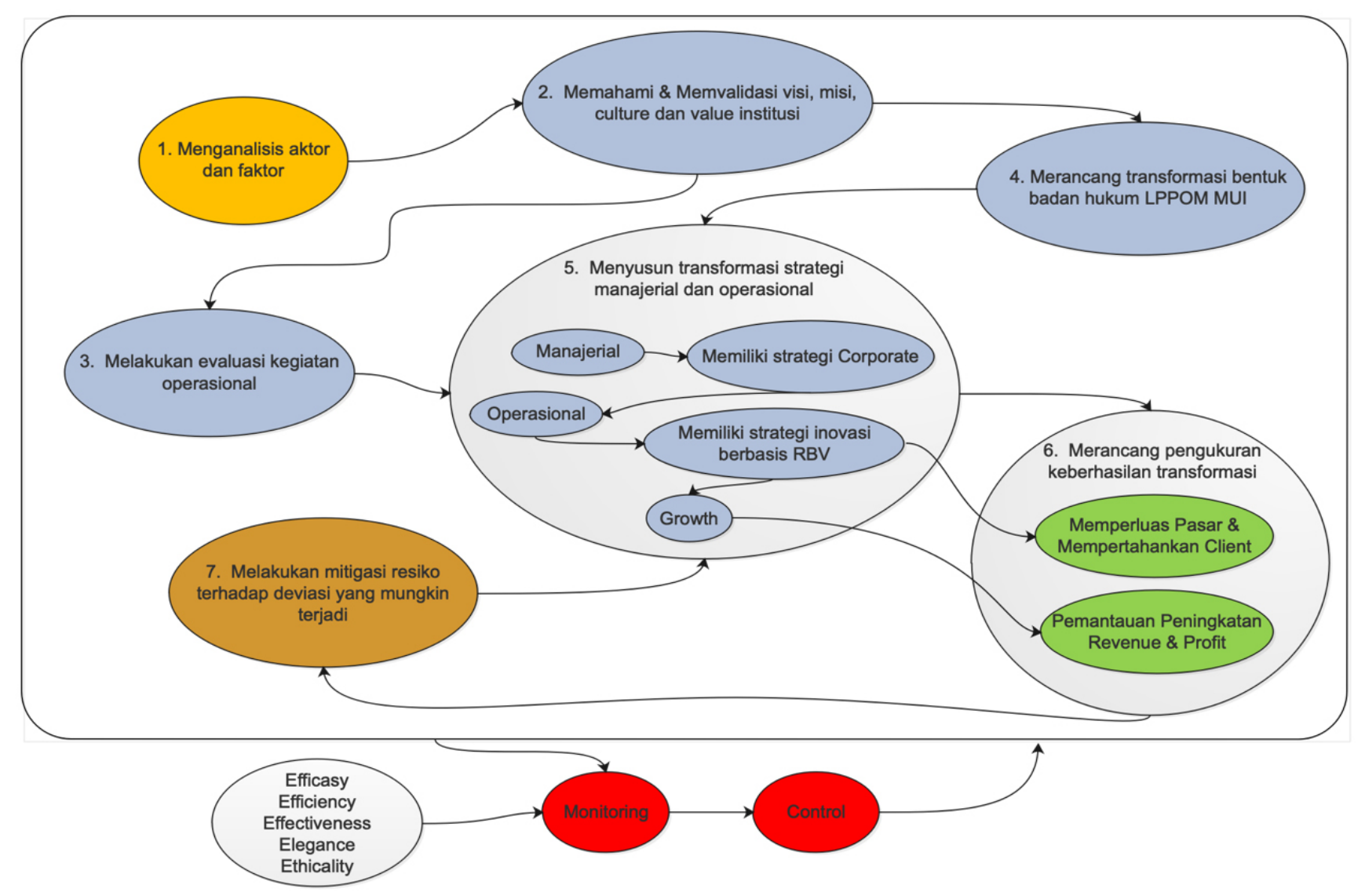

Gambar 3. Model Sistem Transformasi LPPOM MUI 
Tabel 2. Pelaksanaan tahap kelima, keenam dan ketujuh SSM

\begin{tabular}{|c|c|c|c|}
\hline $\begin{array}{c}\text { Aktivitas Model } \\
\text { Konseptual }\end{array}$ & $\begin{array}{c}\text { Deskripsi Aktifitas Dunia } \\
\text { Nyata }\end{array}$ & Kesenjangan yang terjadi & Aksi Penyempurnaan \\
\hline $\begin{array}{l}\text { Menganalisis } \\
\text { Aktor dan Faktor }\end{array}$ & $\begin{array}{l}\text { Membuat Job Deskripsi \& Job } \\
\text { Analysis } \\
\text { Mengevaluasi job deskripsi \& } \\
\text { job analysis }\end{array}$ & $\begin{array}{l}\text { Perlu disesuaikan dengan } \\
\text { konteks regulasi baru } \\
\text { UUJPH }\end{array}$ & $\begin{array}{l}\text { Penyesuaian job deskripsi \& job } \\
\text { analysis sesuai posisinya untuk } \\
\text { mengetahui tanggungjawab \& } \\
\text { karakteristiknya.(Dessler, 2003). }\end{array}$ \\
\hline $\begin{array}{l}\text { Memahami dan } \\
\text { memvalidasi visi, } \\
\text { misi dan obyektif } \\
\text { institusi LPPOM } \\
\text { MUI }\end{array}$ & $\begin{array}{l}\text { Pembuatan dokumen visi, } \\
\text { misi, budaya dan value } \\
\text { institusi sesuai konteks } \\
\text { UUJPH }\end{array}$ & $\begin{array}{l}\text { Visi, Misi, yang ada perlu } \\
\text { disesuaikan serta perlu } \\
\text { ditambahkan culture dan } \\
\text { value yang belum ada }\end{array}$ & $\begin{array}{l}\text { Penyesuian visi, misi, budaya \& value } \\
\text { LPPOM sbg LPH dengan tools OCAI } \\
\text { (organizational culture assessment } \\
\text { instrument) (Cameron \& Quinn, 1999) } \\
\text { Sebuah organisasi harus memiliki } \\
\text { satu keunggulan/ disiplin nilai (value } \\
\text { discipline) sebagai faktor pembeda } \\
\text { dari kompetitornya agar dapat menjadi } \\
\text { pemimpin pasar (Treacy dan Wiersma, } \\
\text { 1997). }\end{array}$ \\
\hline $\begin{array}{l}\text { Melakukan } \\
\text { evaluasi kegiatan } \\
\text { operasional }\end{array}$ & $\begin{array}{l}\text { Melakukan pemetaan kegiatan } \\
\text { dengan kerangka OCAI }\end{array}$ & $\begin{array}{l}\text { Budaya organisasi masih } \\
\text { berada di CLAN }\end{array}$ & $\begin{array}{l}\text { Perumusan strategi operasional } \\
\text { alignment dengan visi \& misi di era } \\
\text { persaingan }\end{array}$ \\
\hline $\begin{array}{l}\text { Merancang } \\
\text { transformasi } \\
\text { institusi }\end{array}$ & $\begin{array}{l}\text { Merancang pemetaan rencana } \\
\text { transformasi }\end{array}$ & $\begin{array}{l}\text { Transformasi belum } \\
\text { dilakukan secara } \\
\text { terstruktur }\end{array}$ & $\begin{array}{l}\text { Menggunakan Balance Scorecard } \\
\text { (BSC) untuk alat ukur dan mengelola } \\
\text { transformasi }\end{array}$ \\
\hline $\begin{array}{l}\text { Melakukan } \\
\text { perbaikan kegiatan } \\
\text { manajerial dan } \\
\text { operasional }\end{array}$ & $\begin{array}{l}\text { Mengidentifikasi dan } \\
\text { mengelaborasi aktivitas } \\
\text { kegiatan manajerial dan } \\
\text { operasional } \\
\text { Melakukan analisis SWOT } \\
\text { Melakukan analisis VRIO }\end{array}$ & $\begin{array}{l}\text { Belum dilakukan secara } \\
\text { menyeluruh }\end{array}$ & $\begin{array}{l}\text { Merumuskan strategi bisis berbasis } \\
\text { analisis SWOT dan VRIO } \\
\text { Mendesain manajemen kinerja untuk } \\
\text { dilaksanakan dan dievaluasi terus } \\
\text { menerus (Cascio, 2006) }\end{array}$ \\
\hline $\begin{array}{l}\text { Merancang. } \\
\text { pengukuran } \\
\text { keberhasilan } \\
\text { transformasi }\end{array}$ & $\begin{array}{l}\text { Mengukur tambahan klien } \\
\text { baru } \\
\text { Mengukur loyalitas klien lama } \\
\text { Mengukur peningkatan } \\
\text { revenue } \\
\text { Mengukur peningkatan profit }\end{array}$ & $\begin{array}{l}\text { Belum dilakukan secara } \\
\text { menyeluruh }\end{array}$ & $\begin{array}{l}\text { Menggunakan alat-alat ukur keuangan } \\
\text { yang relevan untuk memotret } \\
\text { keberhasilan transformasi }\end{array}$ \\
\hline $\begin{array}{l}\text { Melakukan } \\
\text { mitigasi resiko } \\
\text { terhadap deviasi } \\
\text { yang mungkin } \\
\text { terjadi }\end{array}$ & $\begin{array}{l}\text { Mengidentifikasi akar } \\
\text { permasalahan penyebab } \\
\text { deviasi } \\
\text { Mengidentifikasi tindakan } \\
\text { perbaikan agar permasalahan } \\
\text { tidak berulang }\end{array}$ & $\begin{array}{l}\text { Telah dilakukan mitigasi } \\
\text { resiko terhadap kegiatan } \\
\text { manajerial dan operasional }\end{array}$ & $\begin{array}{l}\text { Menerapkan sistem manajemen resiko } \\
\text { ISO31000:2018 dalam mitigasi resiko }\end{array}$ \\
\hline
\end{tabular}

\section{KESIMPULAN DAN SARAN}

\section{Kesimpulan}

Perancangan transformasi institusi penyelenggara dan pengelola sertifikasi halal yaitu LPPOM MUI dilakukan agar fungsi dan perannya tetap berkelanjutan di era regulasi baru (UUJPH) dan tumbuhnya ekosistem halal di era digital industri 4.0. Penelitian ini menghasilkan pengetahuan tentang para aktor, perilakunya, hubungan dan pengaruhnya terhadap proses transformasi LPPOM MUI dan pengembangan strategi corporate dan operasional. Diperoleh delapan hasil utama sebagai strategi kunci dalam transformasi institusi yaitu (i) identifikasi aktor pelaku. Pelaku yang paling berperan adalah MUI dan LPPOM Pusat, (ii) bentuk kelembagaan. Bentuk kelembagaan yang bisa dipilih adalah lembaga bisnis, (iii) evaluasi visi dan misi serta value, (iv) evaluasi operasional berbasis resource based value, (v) transformasi legal institusi, (vi) perbaikan manajerial, (vii) pengukuran kinerja finansial, dan (viii) rencana mitigasi risiko. 


\section{Saran}

Perlu dilakukan kajian strategis untuk pelaksanaan implementasi UUJPH di level Meso (MUI), yaitu dengan membentuk Lembaga di MUI yang menangani amanat. Pada level mikro (LPPOM MUI) perlu dilakukan integrasi bentuk transformasi institusi ke dalam lingkungan internal berupa corporate strategy dan operasional untuk LPPOM MUI pusat dan provinsi.

\section{DAFTAR PUSTAKA}

Azam MSE, Abdullah MA. 2020. Global halal industry: realities and opportunities. IJIBE (International Journal of Islamic Business Ethics) 5(1): 47-59.

[Bappenas] Badan Perencanaan Pembangunan Nasional. 2018. Masterplan Ekonomi Syariah Indonesia 2019-2024. Jakarta: Bappenas.

Bromley DW. 1989. Economic Interest And Institutions: The Conceptual Foundations of Public Policy. New York: Basil Blackwell.

Cameron KS, Quinn RE. 2011. Diagnosing and changing organizational culture: Based on the competing values framework. New Jersey: John Wiley \& Sons.

Cascio, Wayne F. 2006. Managing Human Resources. Colorado: Mc Graw -Hill.

[CIA] Central Intelligence Agency (CIA). 2020. The World Fact Book. https://www.cia.gov/library/ publications/the-world-factbook/geos/id.html, [1 Sep 2020].

Checkland, Peter B, Scholes J. 1990. Soft Systems Methodology in Action. New Jersey: John Wiley \& Sons.

Checkland, Peter B. 1999. Systems Thinking, Systems Practice. New Jersey: John Wiley \& Sons Ltd.

Checkland, Peter B. 2001. Soft Systems Methodology, in J. Rosenhead and J. Mingers (eds), Rational Analysis for a Problematic World Revisited. Chichester: Wiley.

Checkland, Peter B, Poulter J. 2006. Learning for Action: A short definitive account of Soft Systems Methodology and its use for Practitioners, teachers and Students. New Jersey:John Wiley\& Sons Ltd.

Checkland P, Poulter J. 2010. Soft Systems Methodology. Systems Approaches to Managing Change: A Practical Guide. Di dalam: Reynolds M, et al., editor. London, The Open University
2010.

Dessler G. 2003, Manajemen Sumber Daya Manusia. Jilid I. Edisi 10. Penerbit PT Indeks: Jakarta.

Golnaz R et al. 2010. Non-Muslims' awareness of Halal principles and related food products in Malaysia. International Food Research Journal, 17(3): 667-674.

[GIEI] Global Islamic Economy Index. 2018. State of the Global Islamic Economy Report 2018/19. Thomson Reuters.

Hardjosoekarto S. 2012. Soft System Methodology (Metode Serba System Lunak). Jakarta: UIPress.

Hasyim H. 2015. Transformasi pendidikan Islam (Konteks pendidikan pondok pesantren). Jurnal Pendidikan Agama Islam-Ta'lim 13(1): 57-77.

Ho JKK. 2014. Formulation of a systemic PEST analysis for strategic analysis. European academic research 2(5): 6478-6492.

[Kemenag] Kementerian Agama Republik Indonesia - Peraturan Menteri Agama Nomor 26 tahun 2019 tentang Penyelenggaraan Jaminan Produk Halal.

[Kemenag] Kementerian Agama Republik Indonesia. Keputusan Menteri Agama Nomor 982 tahun 2019 tentang Layanan Sertifikasi Halal

[Kemenperin] Kementerian Perindustrian. 2018. Making Indonesia 4.0. Jakarta: Kemenperin.

LPPOM MUI. 2018. Indonesia Halal Directory 2018. Bogor: Penerbit LPPOM MUI.

Novani S, Putro US, Hermawan P. 2014. An application of soft system methodology in batik industrial cluster solo by using service system science perspective. Procedia-Social and Behavioral Sciences 115: 324-331.

Nurrachmi R. 2017. The Global Development of Halal Food Industry: A. Survey. Bogor: Tazkia Islamic Finance and Business Revie

Prasetyaningtyas SW, Sobir S, Hermawan A, Maarif MS. 2019. Utilizing Stakeholders Analysis on Sustainable Organic Farming in West Java: The Case of Cisarua Organic Farming. Jurnal Manajemen \& Agribisnis 16(1): 56-56.

[SekNeg] Sekretariat Negara. Undang-Undang Republik Indonesia Nomor 33 tahun 2014 Tentang Jaminan Produk Halal. Indonesia.

[SekNeg] Sekretariat Negara. Peraturan Pemerintah Republik Indonesia Nomor 31 tahun 2019 tentang Jaminan Produk Halal. Indonesia

Treacy M, Wiersema F. 1997. The Discipline Of Market Leaders: Choose Your Customers, Narrow Your 
Focus, Dominate Your Market. Addison-Wesley, Reading, Massachusetts.

Wilson B. 2001. Soft Systems Methodology Conceptual Model Building and its Contribution. New Jersey: Wiley.

Wurjaningrum F. 2015. Pengaruh aset manajemen proyek dan hasil kinerja manajemen proyek dengan pendekatan VRIO framework (studi kasus pada proyek konstruksi di Surabaya). Jurnal Ekonomi dan Bisnis Airlangga (JEBA) 25(2).

Zulfiandri Z, Maarif MS, Hermawan A, Hardjomidjojo H. 2017. Biaya transaksi dan benefit cost pada integrasi vertikal rantai nilai agroindustri kakao skala kecil. Jurnal Manajemen \& Agribisnis, 14(3): 187-187. 